\title{
Samkvæmni í ávöxtun íslenskra lífeyrissjóða 1997-2017
}

\author{
Gylfi Magnússon ${ }^{1}$
}

\begin{abstract}
Ágrip
Í greininni er lagt mat á samkvæmni í ávöxtun íslenskra lífeyrissjóða, p.e. hvort samband sé á milli ávöxtunar fortíðar og framtíðar. Byggt er á gögnum um ávöxtun allra íslenskra samtryggingarsjóða á árunum 1997 til 2017. Beitt er premur mismunandi tölfræðilegum aðferðum við matið, p.e. aðfallsgreiningu, venslatöflum og MWW aðferð sem byggir á raðsummum. Í ljós kemur að nokkurrar samkvæmni virðist gæta pegar horft er til skamms tíma, p.e. samliggjandi ár skoðuð. Samkvæmnin virðist hins vegar minnka og jafnvel snúast við pegar horft er til lengri tíma. Niðurstöðurnar eru í samræmi við erlendar fyrri rannsóknir á samkvæmni í árangri í eignastýringu og koma pví ekki á óvart. Túlka má niðurstöðurnar pannig að ekki sé vænlegt til árangurs að velja sér lífeyrissjóð eftir fortíðarávöxtun, a.m.k. ekki henni einni saman.
\end{abstract}

\begin{abstract}
This article analyses the performance persistence or consistency of the return on assets for Iceland's mandatory pension funds, i.e. whether past performance gives an indication of future performance. The data used shows the annual real return of all of Iceland's pension funds in the period 1997 until 2017. Three different statistical methods are used, regression analysis, contingency tables and rank-sum analysis (MWW). The conclusion is that performance is only persistent in the short run, when comparing adjacent years, but seems to decrease or even be reversed in the long run. This is in line with findings from previous research in other markets. One practical implication of this is that it does not seem a good strategy to pick a pension fund based on past returns. At least that should not be the main criteria.
\end{abstract}

JEL flokkun: J32; G11; G23

Lykilorð: Samkvæmni; lífeyrissjóðir; ávöxtun; áhætta.

Keywords: Consistency; pension funds; returns; risk.

Performance persistence of Icelandic pension funds 1997-2017

1 Höfundur er dósent í viðskiptafræðideild Háskóla Íslands. Höfundur er jafnframt formaður bankaráðs Seðlabanka Íslands og formaður endurskoðunarnefndar LSR. Greinin er á ábyrgð höfundar og parf ekki að endurspegla skoðanir pessara stofnana. Netfang: gylfimag@hi.is.

This work is licensed under a Creative Commons Attribution 4.0 License.

DOI: https://doi.org/10.24122/tve.a.2019.16.2.1

(c) Tímarit um viðskipti og efnahagsmál 


\section{Inngangur}

Ein af peim spurningum sem sjóðstjórar, fjárfestar og fræðimenn velta mest fyrir sér er hvort og pá hvernig er hægt að áætla árangur við sjóðstjórnun framtíðar út frá árangri fortíðar. Svar við pessari spurningu hefur augljóst hagnýtt gildi, t.d. pegar fjárfestar ákveða hverjum er best að fela fé sitt til ávöxtunar. Ef góður árangur í fortíð gefur fyrirheit um hið sama í framtíð liggur beint við að velja pá sjóði sem skilað hafa bestri ávöxtun sögulega.

Sé hins vegar ekkert samband milli fortíðarávöxtunar og framtíðarávöxtunar skilar pessi stefna litlu. Hún getur jafnvel skilað minna en engu ef sambandið milli fortíðarávöxtunar og framtíðarávöxtunar er neikvætt eða ef mikill kostnaður fylgir pví að eltast við pá sjóði sem hafa glæstustu fortíðartölurnar.

Spurningin er einnig áhugaverð fræðilega, m.a. vegna pess að svarið getur varpað ljósi á pað hve skilvirkir markaðir eru. Ef sami sjóðstjóri eða sjóður getur skilað betri árangri en aðrir að jafnaði ár eftir ár pá samrýmist pað illa tilgátunni um skilvirka markaði (e. Efficient Market Hypothesis, sjá Fama, 1970) sem eyða jafnharðan öllum högnunartækifærum. Sé tilgátan rétt ættu sumir sjóðir (eða sjóðstjórar) að sönnu að standa sig betur tiltekið ár en tilviljun myndi ráða hverjir pað eru og pví ólíklegt að peir sömu standi sig betur en aðrir ár eftir ár. Með öðrum orðum snýst spurningin um sambandið milli fortíðarávöxtunar og framtíðarávöxtunar öðrum præði um pað hvort hæfni (e. skills) eða heppni ráði pví hverjir skila betri ávöxtun en aðrir hverju sinni.

Með samkvæmni í ávöxtun er hér átt við að umframárangur, t.d. ávöxtun umfram viðmið, heldur sér frá einu tímabili til annars. Á ensku er yfirleitt talað um performance persistence eða consistency pótt önnur hugtök séu einnig stundum notuð.

Vegna tengingar lífeyrissjóða við verkalýðsfélög geta íslenskir launpegar í flestum tilfellum ekki fært sig á milli lífeyrissjóða pegar kemur að greiðslu skylduiðgjalds nema með pví að færa sig milli starfa og ganga í nýtt verkalýðsfélag. Petta pýðir að ekki er hægt að nýta með góðu móti upplýsingar um fortíðarávöxtun og samkvæmni í ávöxtun til að velja álitleglegasta sjóðinn til að greiða í. Hluti launpega hefur pó slíkt val og pað á einnig almennt við um pá sem eru sjálfstætt starfandi. Fyrir pá gætu slíkar upplýsingar verið hagnýtar, p.e. ef samkvæmni gætir. Rétt er pó að hafa í huga að fleira skiptir máli við val á lífeyrissjóði en ávöxtun eigna. M.a. skiptir lýðfræði sjóðfélaga máli vegna pess að langlífi og örorkutíðni sjóðfélaga hefur veruleg áhrif á getu lífeyrissjóðs til að greiða út lífeyri eins og nánar er rakið í Gylfi Magnússon (2018).

\section{Fyrri rannsóknir}

Flestar erlendar rannsóknir á samkvæmni í sjóđstjórnun horfa til einhvers konar verðbréfasjóða ${ }^{2}$ (e. mutual fund). Brautryðjendaverk á pessu sviði var grein Jensen (1968). Hann skoðaði gögn um ávöxtun bandarískra sjóða frá 1945 til 1964. Jensen byggði greiningu sína á CAPM-líkaninu og var niðurstaða hans annars vegar að sjóðirnir hefðu að meðaltali ekki staðið sig betur en náðst hefði með pví að elta markaðinn í heild (p.e. fylgja hlutlausri eignastýringu, kaupa og eiga markaðinn, „,M“) og hins vegar að mjög lítið benti til pess að einstakir sjóðir gætu náð betri árangri en markaðurinn nema fyrir tilviljun. Margar síðari rannsóknir á samkvæmni hafa byggt á svipaðri nálgun, p.e. notað áhættuleiðrétta ávöxtun skv. CAPM sem viðmið. Pá er beta ( $\beta$ ) sjóðs, p.e. samfylgni ávöxtunar sjóðsins og markaðsvísitölu í hlutfalli við dreifni ávöxtunar vísitölunnar, notuð sem mælikvarði á pá áhættu sem sjóðurinn tekur.

Einnig pekkist að nota aðra áhættumælikvarða og er staðalfrávik ávöxtunar algengast. Algengt afbrigði af pví er að reikna út svokallað Sharpe-hlutfall fyrir sjóði en pað er

2 Í lögum nr. 128/2011 um verðbréfasjóði, fjárfestingarsjóði og fagfjárfestasjóði er hugtakið verðbréfasjóður skilgreint pröngt að evrópskri fyrirmynd og einungis notað um sjóði sem uppfylla skilyrði tilskipunar 2014/91/EU (UCITS). Hér verður hugtakið notað í almennari merkingu, p.e. um allar prjár tegundirnar sem tilgreindar eru í lögunum, enda eru margar peirra rannsókna sem vísað er til byggðar á gögnum frá Bandaríkjunum par sem flokkun sjóða er með nokkuð öðrum hætti en á evrópska efnahagssvæðinu. 
áhættupóknun (ávöxtun umfram áhættulausa vexti) í hlutfalli við staðalfrávik ávöxtunar. Hlutfallið er einnig pekkt sem halli línu fjármagnsmarkaðar (e. capital market line). Hlutfallið var sett fram af William Sharpe (1966) í öðru brautryðjendaverki í pessum fræðum. Sharpe skoðaði ávöxtun 34 bandarískra verðbréfasjóða 1954-63. Niðurstöður hans voru nokkuð aðrar en Jensen, p.e. hann fann nokkra samkvæmni í áhættuleiðréttri ávöxtun. Pessa samkvæmni rakti hann einkum til pess að kostnaðarhlutföll sumra sjóða voru lægri en annarra. Pannig sýndu sjóðir með lágan rekstrarkostnað marktækt betri árangur en aðrir til langs tíma í úrtaki Sharpe.

Í síðari tíma rannsóknum á árangri í sjóðstjórnun er algengt að í stað einfaldra áhættuleiðréttinga sé stuðst við árangursviðmið (e. benchmark). Fyrrnefnd grein Jensen gaf raunar tóninn par sem m.a. var notaður samanburður við hlutlausa eignastýringu. Slíkt árangursviðmið er enn algengt, p.e. árangur borinn saman við vísitölu. Hver vísitalan er fer oftast eftir eðli sjóðsins sem til skoðunar er, p.e. hlutabréfavísitala er notuð fyrir hlutabréfasjóð og skuldabréfavísitala fyrir skuldabréfasjóð. Einnig pekkjast samsettar vísitölur og sérhæfðari vísitölur. Angelidis o.fl. (2013) telja pað gefa ranga mynd af árangri að bera ávöxtun saman við almenna vísitölu fyrir viðkomandi markað, t.d. S\&P-500 fyrir sjóð sem fjárfestir í bandarískum hlutabréfum. Í pess stað eigi að bera árangur saman við pað árangursviðmið sem sjóðurinn sjálfur miðar við (e. self-reported benchmark).

Fyrrnefndar rannsóknir skoða eingöngu ávöxtun sjóða en ekki sjóðstjóra, p.e. ekki er reynt að leggja mat á hvort árangur megi rekja til tiltekinna sjóðstjóra. Ýmsar síðari rannsóknir hafa hins vegar gert pað og m.a. lagt mat á hvort sjóðstjóraskipti hafa marktæk áhrif á árangur sjóðs. Sem dæmi má nefna Clare o.fl. (2014) sem skoða breska sjóði á tímabilinu 1997-2011. Pau komast að peirri niðurstöðu að sjóðstjóraskipti hafi marktæk áhrif á árangur. Sérstaklega komi pað niður á árangri sjóðs ef sjóðstjóri sem hefur náð betri árangri en viðmið lætur af störfum en geti bætt árangur ef sjóðstjóri sem hefur náð lakari árangri en viðmið lætur af störfum.

Pá hafa nýlegar rannsóknir lagt mat á hvort pað skipti máli hvort sjóði er stjórnað af einum sjóðstjóra eða hópi. Ekki hafa fengist skýrari niðurstöður um pað efni. Chen o.fl. (2004) telja að hópar skili lakari árangri en einstaklingar en Han o.fl. (2008) kemst að öfugri niðurstöðu.

Af nýlegum rannsóknum á pví má nefna Adams, Nishikawa og Rao (2018). Peir finna veika vísbendingu um að betri árangri náist með hópstjórnun. Skýringuna á pví að áhrifin eru ekki sterk telja peir einkum að ýmis vel pekkt vandamál við hópstarf, svo sem laumufarpegavandi (e. free rider problem) geti dregið úr skilvirkni hópanna. Pegar tekið sé á slíkum vandamálum með sterku eftirliti félagsstjórnar virki hópar hins vegar vel við eignastýringu.

Grau-Carles o.fl. (2017) skoða ávöxtun breskra verðbréfasjóða á tímabilinu 2000-2010 og sýna fram á að röðun sjóða eftir árangri er mjög viðkvæm fyrir peim árangursmælikvörðum sem stuðst er við. Peir leggja til nýja aðferð við að meta árangur sem velur árangursmælikvarða eftir pví hver gefur stöðugasta árangursmatið.

Hunter o.fl. (2014) skoða einnig árangursmælikvarða. Peir leggja til að auk hefðbundinna mælikvarða sem byggja á páttalíkönum (e. factor model) pá sé árangur borinn saman við ávöxtun sem fengist hefði með pví að fela öllum sjóðum í sama flokki jafnháa upphæð til ávöxtunar (e. active peer benchmark). Niðurstaða peirra er að sé pessi aðferð notuð við að velja sjóð til að fjárfesta í pá skili pað marktækri aukningu framtíðarávöxtunar.

Jenkinson o.fl. (2016) skoða ráðleggingar fjárfestingarráðgjafa (e. investment consultants) um val á sjóðstjórum. Peir skoða bandaríska sjóði í virkri stýringu og greina hvað ræður ráðleggingum ráðgjafanna. Niðurstaðan er að pótt ráðgjöfin hafi veruleg áhrif á fjárstreymi til einstakra sjóða pá skili hún engum virðisauka fyrir fjárfesta. Pað er í samræmi við kenninguna um skilvirka markaði að hluta, p.e. styður við að markaðurinn fyrir sjóðstjórnun sé skilvirkur, en samræmist ekki kenningunni pegar kemur að markaðinum fyrir fjármálaráðgjöf. 
Moneta (2015) skoðar bandaríska skuldabréfasjóði í virkri stýringu og kemst að peirri niðurstöðu að stýringin skili nokkurn veginn nægri umframávöxtun (1\%) til að standa undir kostnaði við rekstur sjóðanna og gjaldtöku af fjárfestum. Pessi niðurstaða bendir til pess að hagkvæmara gæti verið að fjárfesta í slíkum sjóðum frekar en að kaupa beint í peim eignaflokkum sem fjárfest er í og beita hlutlausri stýringu.

Vidal-García (2013) skoðar evrópska hlutabréfasjóði á tímabilinu 1988-2010. Hann finnur sterkar vísbendingar um samkvæmni til eins árs og nokkra vísbendingu um samkvæmni til lengri tíma, allt að priggja ára. Samkvæmnin er einkum skýr fyrir pá sjóði sem eru annað hvort nær toppi eða botni í árangri.

Vidal García o.fl. (2016) skoða samkvæmni til skamms tíma í alpjóðlegu gagnasafni á tímabilinu 1990-2013. Peir finna skýra vísbendingu um samkvæmni til skamms tíma (eins ársfjórðungs) en hún fjarar hratt út pegar horft er til lengri tíma. Samkvæmnin er jafnframt sterkust fyrir pá sjóði sem eru annað hvort nærri toppi eða botni í ávöxtun hverju sinni.

Ein íslensk rannsókn hefur verið birt á samkvæmni í ávöxtun verðbréfasjóða (Gylfi Magnússon o.fl., 2010). Byggt er á gögnum frá 1998-2005 um nær alla verðbréfasjóði sem störfuðu á tímabilinu. Einungis veikar vísbendingar um samkvæmni fundust í peirri rannsókn.

Pá er stuttlega vikið að samkvæmni í ávöxtun lífeyrissjóða í Gylfi Magnússon (2018). Par er borin saman ávöxtun fyrir hrun og í hruni, p.e. 1997-2008, og ávöxtun eftir hrun, p.e. 2009-2017. Niðurstaðan er að ávöxtun á fyrra tímabilinu gaf enga skýra vísbendingu um ávöxtun á síðara tímabilinu.

\section{Gögn}

Byggt er á ávöxtunartölum íslenskra lífeyrissjóða tímabilið 1997-2017. Frumgögnin eru að mestu frá FME sem tekur saman gögn frá lífeyrissjóðunum sjálfum. Um ársgögn er að ræða. FME birtir ávöxtunartölur en ávöxtun er hér reiknuð að nýju út frá breytingu á bókfærðu virði eigna sjóðanna umfram hrein iðgjöld. Gögnunum og aðferðafræði við útreikninga er nánar lýst í (Gylfi Magnússon, 2018). Par er einnig ítarleg umfjöllun um ávöxtun o.fl. á mismunandi tímabilum. Í nær öllum tilfellum eru sömu ávöxtunartölur notaðar í pessari rannsókn en einnig er bætt við nýjum útreikningum á ávöxtun út frá markaðsvirði í stað bókfærðs virðis eigna. ${ }^{3}$

Lífeyrissjóðum hefur fækkað mjög á tímabilinu vegna sameininga. Er vegna pess bæði horft á ávöxtun peirra sjóða sem voru til á hverjum tíma en einnig reiknuð ávöxtun peirra sjóða sem störfuðu í lok tímabilsins að teknu tilliti til ávöxtunar allra forvera peirra. Рað er gert með pví að reikna út ávöxtun sjóðs sem nú starfar eins og að peir samrunar sem hann kann að hafa gengið í gegnum hafi allir orðið í upphafi tímabilsins.

\section{Aðferðafræði}

Nokkrar aðferðir koma til greina við mat á samkvæmni eins og sjá má á peim rannsóknum sem reifaðar eru hér að framan í kaflanum um fyrri rannsóknir. Hér verða í grundvallaratriðum prjár aðferðir notaðar, ein stikuð (e. parametric) og tvær óstikaðar (e. non-parametric).

Stikaða aðferðin byggir á einfaldri aðfallsgreiningu par sem skýrða stærðin er ávöxtun

3 Lífeyrissjóðir hafa heimild FME til að færa skuldabréf sem peir hyggjast halda til gjalddaga á uppfærðu kaupverði miðað við ávöxtunarkröfu við kaup. Раð er undantekning frá peirri almennu reglu að færa eignir á markaðsvirði. Pegar ávöxtunarkrafa markaðarins breytist eftir að viðskipti hafa átt sér stað pýðir petta að bókfært virði verður annað en markaðsvirði. Pegar vextir fara almennt lækkandi eins og gerst hefur undanfarin ár verður bókfært virði lægra en markaðsvirði. Lífeyrissjóðir nýta sér pessa heimild í mismiklum mæli og sumir alls ekki. Pví verða útreikningar á hreinni eign til greiðslu lífeyris og ávöxtun ekki alveg sambærilegir á milli sjóða. Sjóðir sem færa ekki öll skuldabréf á markaðsvirði hafa pó undarin ár almennt gefið upp markaðsvirðið í skýringum við ársreikninga. аð gerir pað kleift að endurreikna ávöxtun peirra sjóða pannig að hún verði sambærileg við ávöxtun hinna. 
á síðara tímabili en skýristærðin er ávöxtun á fyrra tímabili, sjá jöfnu 1. Gögnin sem byggt er á sjást á myndum 1 og 2 .

$$
\overline{r_{s}}-V_{s}=\alpha+\beta \cdot\left(\overline{r_{f}}-V_{f}\right)+e_{s}
$$

Par sem $\overline{r_{s}}$ er ávöxtun seinna tímabilið og $\overline{r_{f}}$ ávöxtun fyrra tímabilið, $V_{f}$ er viðmið ávöxtunar fyrra tímabilið og $V_{s}$ viðmið síðara tímabilið. $e_{s}$ er leifaliður og $\alpha$ og $\beta$ metnir stuðlar.

Tímabilin geta verið eitt eða fleiri ár. Ávöxtunartölur geta ýmist verið notaðar óbreyttar (pá eru $V_{s}$ og $V_{f}$ núll) eða ávöxtun reiknuð sem frávik frá meðalávöxtun allra sjóða á viðkomandi tímabili (pá eru $V_{s}$ og $V_{f}$ meðalávöxtunin) eða frávik frá ávöxtun reiknaðs viðmiðs (pá eru $V_{s}$ og $V_{f}$ ávöxtun viðkomandi viðmiðs).

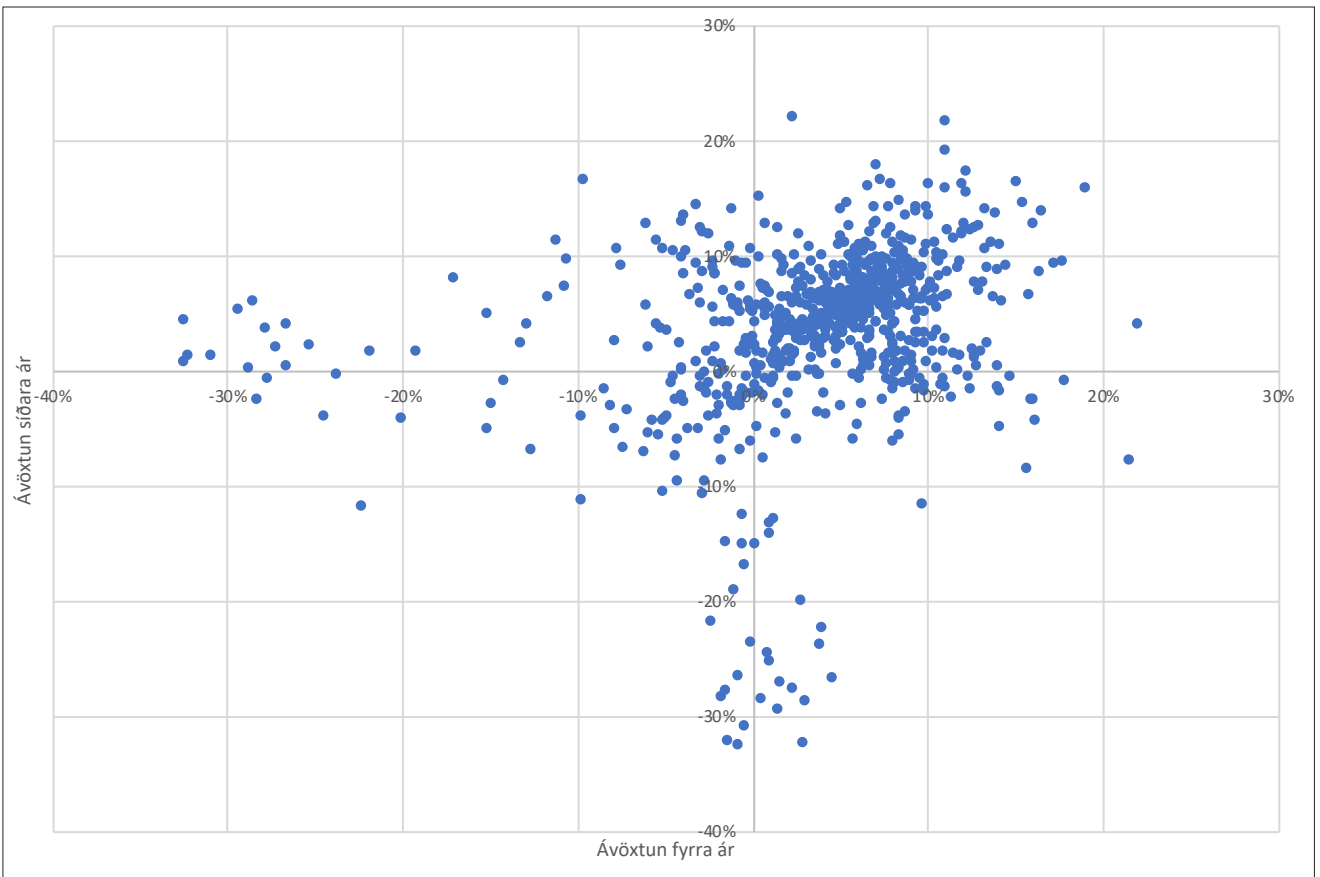

Mynd 1. Raunávöxtun samliggjandi ára

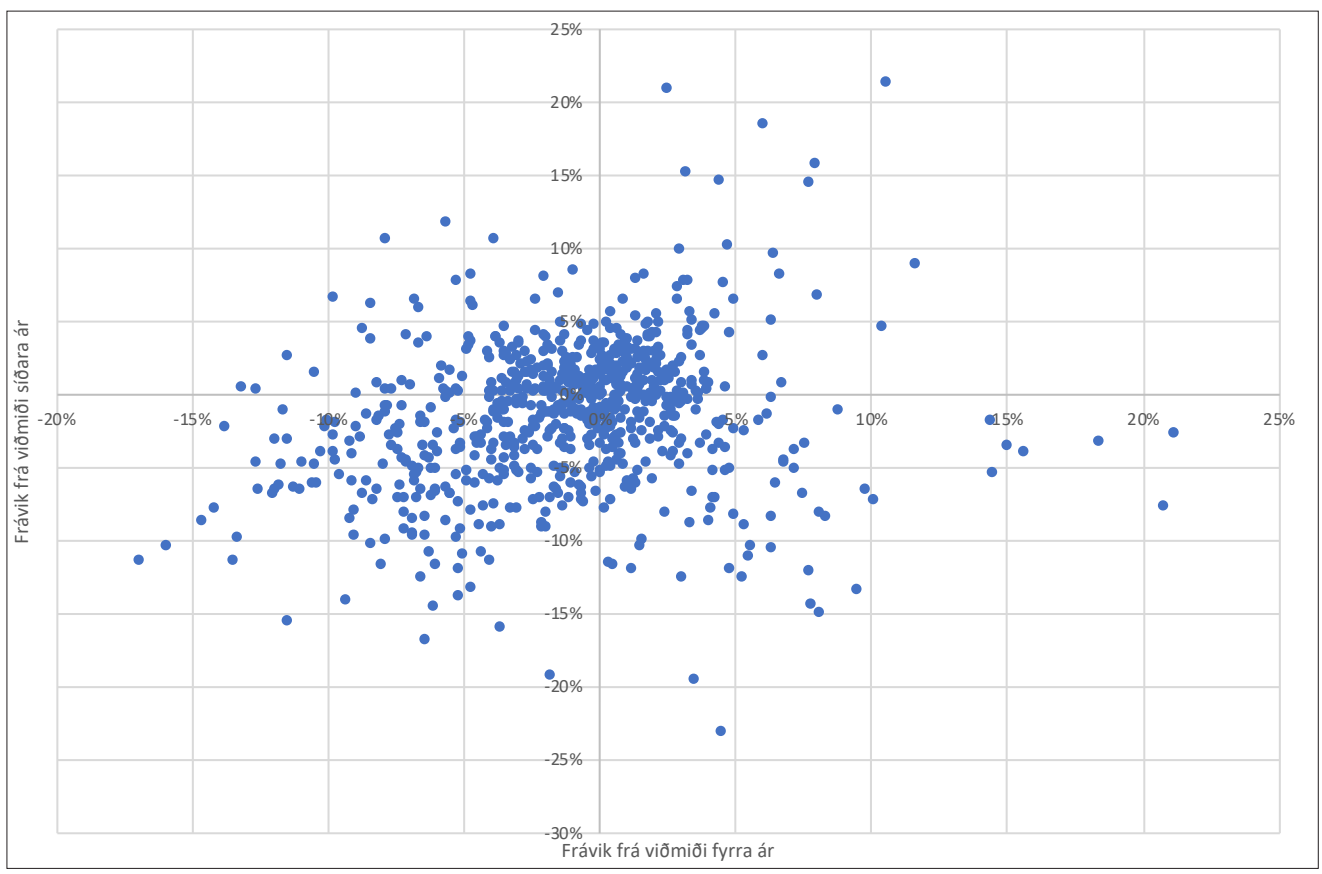

Mynd 2. Frávik frá ávöxtunarviðmiði samliggjandi ára 
Pegar reiknuð er ávöxtun umfram viðmið er notað sama viðmið og í (Gylfi Magnússon, 2018). Раð viðmið byggir á premur eignaflokkum, innlendum og erlendum hlutabréfum og áhættulausum verðtryggðum langtímavöxtum í krónum og vægi hvers eignaflokks er reiknað út frá áætluðu vægi í eignasöfnum allra lífeyrissjóða á hverjum tíma.

Í greiningu með stikuðu aðferðinni eru t-próf notuð til að leggja mat á marktækni. Pótt pessi aðferð geti varpað nokkru ljósi á samkvæmni eru ýmis vel pekkt aðferðafræðileg vandamál við að beita einfaldri aðfallsgreiningu á gögn sem pessi. M.a. er forsenda t-prófa um normaldreifingu ekki uppfyllt ${ }^{4}$ auk pess sem misdreifni og sjálffylgni eru líkleg vandamál. Pví verður meira lagt upp úr óstikuðu aðferðunum sem byggja ekki á sömu ströngu og líklega röngu forsendum og aðfallsgreiningin.

Fyrri óstikaða aðferðin byggir á venslatöflum (e. contingency table). Pá er sjóðum skipt í tvo hópa á hverju tímabili. Pá sem stóðu sig vel, p.e. náðu góðri ávöxtun, par sem skilyrðið er að hafa náð ávöxtun yfir miðgildi sjóðanna, og pá sem stóðu sig ver. Síðan er greint hvort færsla sjóða á milli hópa frá einu tímabili til annars virðist tilviljunarkennd. Ef jafnlíklegt virðist að sjóður sem stóð sig vel á fyrra tímabili standi sig vel eða illa á síðara tímabili er samkvæmni ekki til staðar. Ef sjóður sem stóð sig vel (illa) á fyrra tímabili er líklegur til að standa sig einnig vel (illa) á síðara tímabili er um samkvæmni að ræða. Einnig er hugsanlegt að ósamkvæmni mælist, p.e. sjóður sem stóð sig vel (illa) á fyrra tímabili sé líklegur til að standa sig illa (vel) á síðara tímabili. Pá gæti verið um einhvers konar endurhvarf til miðjunnar (e. reversal to the mean) að ræða. Venslatöflur eru einnig notaðar í (Gylfi Magnússon o.fl. 2010) og eru pví niðurstöður fyrir lífeyrissjóði hér að nokkru leyti samanburðarhæfar við niðurstöður fyrir verðbréfasjóði par. Sjá jöfnu 2.

$$
Q=\frac{\left[N_{H, H}-E\right]^{2}+\left[N_{H, L}-E\right]^{2}+\left[N_{L, H}-E\right]^{2}+\left[N_{L, L}-E\right]^{2}}{E}
$$

Hér táknar $N$ fjölda sjóða og E væntan fjölda, p.e. fjölda sem búast mætti við í hverjum flokki að jafnaði ef $H_{0}$ er rétt og engin samkvæmni er í ávöxtun. $H$ vísar til sjóða með „hárri“ ávöxtun, p.e. yfir miðgildi og $L$ til peirra sem eru með „lága“ ávöxtun, p.e. undir miðgildi. Fótskriftin $H, L$ táknar pannig t.d. sjóði sem eru með háa ávöxtun á fyrra tímabili en lága á seinni. Sé tilgátan $H_{0}$ rétt, að engin samkvæmni sé í ávöxtun, p.e. jafnlíklegt sé að sjóður í hvort heldur flokki $\mathrm{H}$ eða L á fyrra tímabili sé í hópi $\mathrm{H}$ og í hópi L á pví síđara, pá fylgir Q kí-kvaðrat dreifingu með einni frígráðu (DeGroot, 1986, bls. 337). Mynd 3 sýnir hvernig skiptingin í hina fjóra flokka í jöfnu 2 próaðist yfir tíma.

Síðari óstikaða aðferðin byggir á nánari greiningu á röð sjóða eftir ávöxtun en venslatöflurnar. Einn veikleiki venslatöflunálgunarinnar er að hún byggir á grófri flokkun í tvo hópa (pó er vitaskuld hægt að reikna út venslatöflur fyrir fínni skiptingu) en nota ekki til fulls upplýsingar um röð innan hvers hóps eða innan heildarúrtaksins. Annar veikleiki pessarar nálgunar er að hún greinir ekki sjálfkrafa á milli pess hvort $H_{0}$ er hafnað vegna mikillar samkvæmni eða mikillar ósamkvæmni. ${ }^{5}$

Í síðari óstikuðu aðferðinni sem beitt er verður pví stuðst við svokallað Mann-Whitney-Wilcoxon ${ }^{6}$ próf $(\mathrm{MWW})$ sem leggur mat á hvort breytingar á röðun milli tímabila eru kerfisbundnar eða tilviljunarkenndar og ef $H_{0}$ er hafnað kemur skýrt fram hvort pað er vegna samkvæmni eða ósamkvæmni. Sjá jöfnu 3.

$$
W=\sum_{t=1998}^{2017}\left[\sum_{L_{t-1}}\left(R_{t}^{i}-E\left(R_{t}^{i}\right)\right)-\sum_{H_{t-1}}\left(R_{t}^{i}-E\left(R_{t}^{i}\right)\right)\right]
$$

4 Tímaraðir um ávöxtun hvort heldur er einstakra sjóða eða sjóðanna sem heildar kolfalla á Jarque-Bera prófi.

5 Рað er pó tiltölulega einfalt að sjá hvort er tilfellið með pví að skoða gögnin en vegna pessa eiginleika eru líkindareikningar sem fást út frá venslatöflunum (jafna 2) ekki alveg sambærilegir við pá sem fást út frá MWW prófi (jafna 3).

6 Einnig pekkt undir heitinu Mann Whitney U próf eða Wilcoxon raðsummu (e. rank sum) próf. 


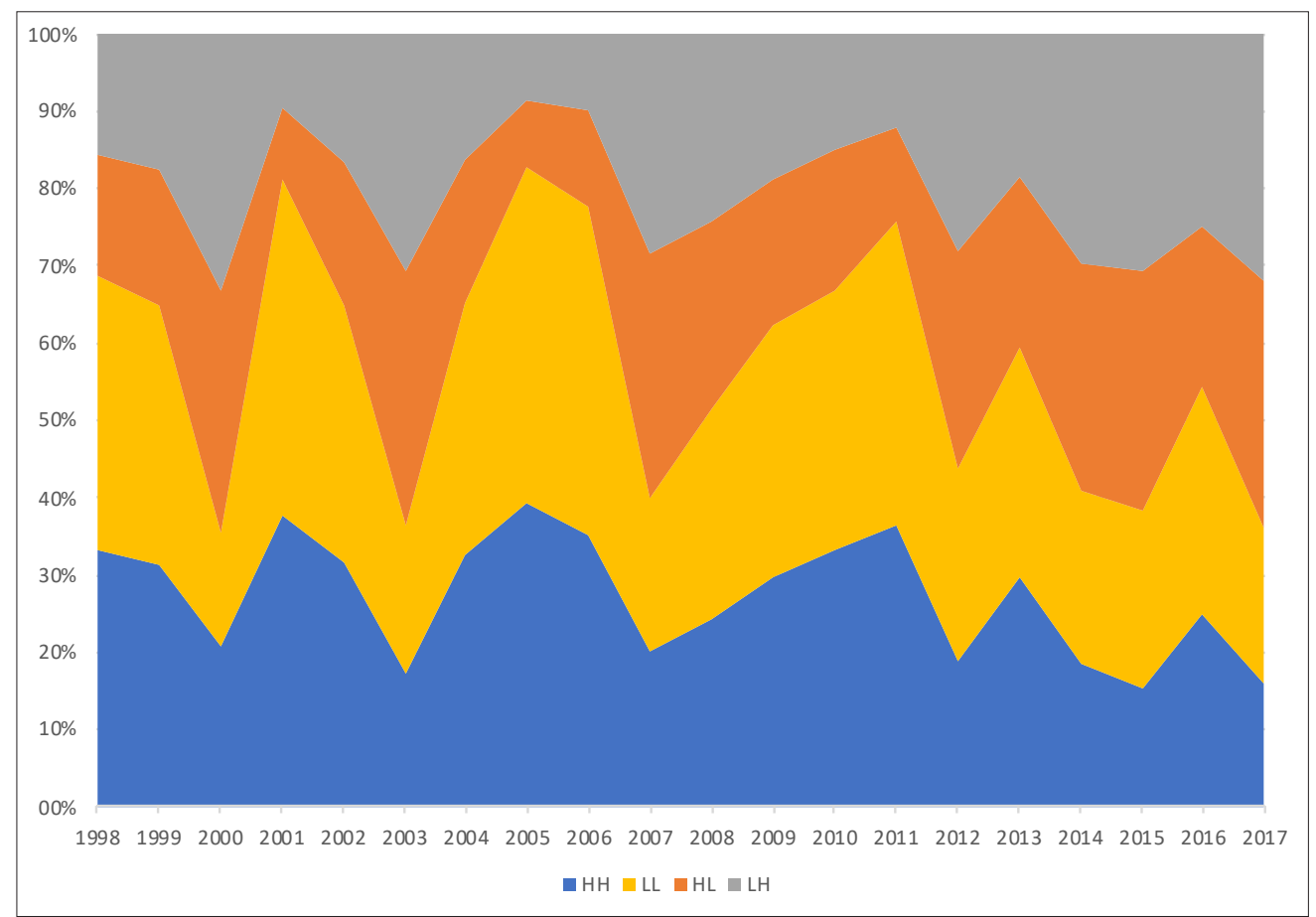

Mynd 3. Samkvæmni einstakra ára

(HH+LL samkvæmni, HL+LH ósamkvæmni)

Hér táknar $R_{t}^{i}$ raðtölu og $E\left(R_{t}^{i}\right)$ vænta raðtölu sjóðs $i$ á ári $t$. Vænt raðtala er einfaldlega meðalraðtala tiltekið ár sé $H_{0}$ rétt. Ef samkvæmni gætti í ávöxtun ættu peir sem voru í lægri hóp (L) á fyrra tímabili almennt að vera með hærri raðtölu (par sem sjóðurinn með hæstu ávöxtunina er númer 1 o.s.frv.) en sjóðir sem voru í hærri hóp (H) á fyrra tímabili. Pá ætti stuðullinn $W$ að mælast jákvæður.? Ef hvorki væri um samkvæmni eða ósamkvæmni að ræða ætti $W$ að vera nálægt núlli. Til að meta líkindadreifingu $W$ ef $H_{0}$ er rétt (hvorki samkvæmni né ósamkvæmni) var notað einfalt hermilíkan sem raðaði sjóðum af handahófi á hverju ári. Hermilíkanið var keyrt 5.000 sinnum og $W$ reiknað út fyrir hverja keyrslu til að fá líkindadreifingu fyrir $W$ til að bera saman við niðurstöðurnar úr jöfnu (3) og meta tölfræðilega marktækni niðurstaðnanna.

Tafla 1. Mat á jöfnu 1, öll ár.

Án áhrifa samruna

Skýristærð ávöxtun ársins á undan

\begin{tabular}{lcccccc}
\hline & $\beta$ & $t$ & $p$ & $r^{2}$ & $F$ & Frelsisgráður \\
\hline Hráar tölur & 0,25 & 7,00 & $0,00 \%$ & $6,1 \%$ & 49,121 & 755 \\
\hline Frávik frá meðaltali & 0,18 & 4,87 & $0,00 \%$ & $3,0 \%$ & 23,739 & 755 \\
\hline Frávik frá viðmiði & 0,22 & 5,88 & $0,00 \%$ & $4,4 \%$ & 34,567 & 755 \\
\hline
\end{tabular}

Jafna 3 gerir ráð fyrir að samkvæmni sé metin út frá ávöxtun samliggjandi ára. Einnig var miðað við lengri tímabil til að skoða hvort samkvæmni gætti í ávöxtun til lengri tíma en eins árs.

$7 \quad$ byggir á mismuninum á annars vegar summu raðtalna peirra sjóða sem voru með lága ávöxtun (og pví háa raðtölu) á fyrra tímabili og hins vegar summu raðtalna peirra sem voru með háa ávöxtun (lága raðtölu) á fyrra tímabili. Ef um samkvæmni er að ræða hafa sjóðir sem voru með lága raðtölu áður tilhneigingu til að vera áfram með lága raðtölu síðar og summa raðtalna peirra pví áfram lág. Sömuleiðis haldast raðtölur háar í framtíð fyrir sjóði sem voru með háar raðtölur í fortíð. Munurinn á summu raðtalna pessara hópa, p.e. $W$, er pví jákvæður pegar summa síðari hópsins er dreginn frá summu pess fyrri sé samkvæmni í ávöxtun. Sé um ósamkvæmni að ræða snýst petta við og $W$ verður neikvætt. 


\section{Tölulegt mat}

\subsection{Samkvæmni til skamms tíma (eins árs)}

Við mat á samkvæmni til eins árs voru allar prjár aðferðir (jöfnur 1-3) að ofan notaðar. Jafnframt var bæði skoðuð samkvæmni fyrir einstök pör ára og fyrir öll árin saman. Pegar öll árin voru skoðuð saman kom í ljós skýr samkvæmni, p.e. góð (slæm) ávöxtun tiltekins árs gaf fyrirheit um góða (slæma) ávöxtun árið á eftir í samanburð við aðra lífeyrissjóði. Áhrifin voru tölfræðilega marktæk og höfðu einnig efnahagslega pýðingu. Einu prósentustigi hærri ávöxtun tiltekið ár skilaði að jafnaði rétt um 0,2 prósentustigum hærri ávöxtun árið á eftir. Tafla 1 sýnir helstu niðurstöður.

Mat á jöfnum 2 og 3 skilaði einnig peirri niðurstöðu að samkvæmni gætti til eins árs. Pannig var stuðullinn $W=2.104$ við mat á jöfnu 3 og engin af keyrslunum 5.000 í hermilíkaninu skilaði svo háu $W$ sem pýðir að $p<1 / 5.000$ á að $H_{0}$ sé rétt. Mat á jöfnu 2 skilaði $Q=5,39$ sem samsvarar $p=2,03 \%$. Samkvæmnin lýsti sér pannig að af peim sjóðum sem voru fyrir ofan miðgildi $(H)$ fyrra árið voru $57,4 \%$ einnig fyrir ofan miðgildi árið á eftir en $42,6 \%$ fyrir neðan. Sömuleiðis voru 60,2\% peirra sem voru fyrir neðan miðgildi $(L)$ tiltekið ár einnig fyrir neðan miðgildi árið á eftir en 39,8\% fyrir ofan. Myndir 1 og 2 sýna ávöxtunarpörin (p.e. ávöxtun fyrra árs og síðara árs), annars vegar miðað við raunávöxtun hvers árs (mynd 1) og hins vegar miðað við frávik frá viðmiði (mynd 2) og mynd 3 skiptingu í flokka eftir hárri og lágri ávöxtun. Sjá einnig töflur $V 1$ og $V 2$ í viðauka.

Pegar ávöxtun einstakra samliggjandi ára var skoðuð kom í ljós að flest árin gætti nokkuð skýrrar samkvæmni. Nokkur áranna snerist samkvæmnin hins vegar við, p.e. góðri (slæmri) ávöxtun fyrra árið fylgdi slæm (góð) ávöxtun síðara árið. Petta getur átt sér einfaldar hagrænar skýringar. T.d. gætu sjóðir með svipaða fjárfestingarstefnu (sem dæmi mjög mikla áherslu á hlutabréf) allir náð góðri ávöxtun á peim árum par sem hún gefur vel af sér (pegar hlutabréfaverð hækkar) og pað jafnvel gerst nokkur ár í röð. Sjóðirnir með pessa stefnu gætu síðan allir skilað slæmri ávöxtun á ári par sem hún reynist illa (pegar hlutabréfaverð lækkar).

Ofangreindar tölur voru allar reiknaðar út frá tölum um einstaka lífeyrissjóði eins og peir voru reknir á hverjum tíma en ekki tekið tillit til fjölmargra samruna sem urðu á tímabilinu. Einnig var samkvæmni skoðuð miðað við ávöxtun núverandi sjóða og allra forvera peirra. аð jafngildir pví að gera ráð fyrir að samrunar sem urðu einhvern tíma á tímabilinu hafi allir orðið í upphafi tímabilsins. Tafla 2 sýnir niðurstöðurnar fyrir jöfnu 1. Mat á stuðlum jafna 2 og 3 skilaði sambærilegum niðurstöðum og pað sem sjá má í töflu 2 og renndi stoðum undir að samkvæmni gætti.

Tafla 2. Mat á jöfnu 1, öll ár

Núverandi sjóðir að teknu tilliti til ávöxtunar forvera

Skýristærð ávöxtun ársins á undan

\begin{tabular}{lcccccc}
\hline & $\beta$ & $t$ & $p$ & $r^{2}$ & $F$ & Frelsisgráður \\
\hline Hráar ávöxtunartölur & 0,22 & 4,99 & $0,00 \%$ & $4,8 \%$ & 24,913 & 492 \\
\hline Frávik frá meðaltali & 0,16 & 3,69 & $0,00 \%$ & $2,7 \%$ & 13,648 & 492 \\
\hline Frávik frá viðmiði & 0,22 & 4,91 & $0,00 \%$ & $4,7 \%$ & 24,094 & 492 \\
\hline
\end{tabular}

Ávöxtunartölurnar að baki fyrrgreindum niðurstöðum eru byggðar á bókfærðu virði eigna eins og pað er skráð hjá FME. Bókfært verð er hins vegar ekki í öllum tilfellum hið sama og markaðsverð, eins og nánar var fjallað um hér að framan. Раð pýðir jafnframt að mat á ávöxtun verður ekki hið sama og fengist út frá markaðsvirði. Til að kanna hvort petta hefði áhrif á mælda samkvæmni var safnað peim gögnum sem hægt var með góðu móti fyrir markaðsverð eigna en undanfarin ár hafa lífeyrissjóðir sem ekki færa allar eignir á markaðsvirði yfirleitt jafnframt gefið upp markaðsvirði í skýringum við ársreikninga. Hægt var að finna markaðsvirði nær allra lífeyrissjóða í árslok 2015 til 2017. Með pessum 
hætti var hægt að endurreikna ávöxtunartölur tveggja ára, 2016 og 2017. Par með var hægt að skoða hvort ávöxtun ársins 2016 skýrði ávöxtun ársins á eftir. Hér er vitaskuld um mjög afmarkaða skoðun að ræða og mun takmarkaðari en pegar öll árin 1997-2017 eru undir. Niðurstöðurnar gáfu veika vísbendingu um ósamkvæmni $(\beta=-0,11, t=-0,91, p=18,7 \%)$.

\subsection{Samkvæmni til lengri tíma en eins árs}

Auk pess að skoða hvort ávöxtun tiltekins árs hefur forspárgildi fyrir ávöxtun árið á eftir voru lengri tímabil skoðuð. Bæði hvort ávöxtun tiltekins árs skýrði ávöxtun tveimur árum síðar og hvort meðalávöxtun 5 ára ávöxtun skýrði meðalávöxtun næstu fimm ára. Pegar samkvæmni til lengri tíma en eins árs er skoðuð pá flækir pað málið töluvert hve mikið var um samruna á tímabilinu. Ef t.d. leggja á mat á hvort ávöxtun 5 ára hefur forspárgildi fyrir ávöxtun næstu 5 ára á eftir pá parf 10 ára samfellda sögu sama lífeyrissjóðs fyrir hverja mælingu. Ef sleppt er sjóðum sem ekki eiga svo langa samfellda sögu er hætta á pví að úrtakið verði bæði smátt og pjakað af seiglubjögun (e. survivorship bias). Til að komast hjá pessum vanda var ákveðið að horfa hér eingöngu á ávöxtunartölur núverandi sjóða að teknu tilliti til ávöxtunar forvera hvers og eins. M.ö.o. voru ávöxtunartölur endurreiknaðar eins og að allir samrunar sem orðið hafa á pví tímabili sem er til skoðunar hefðu orðið í upphafi tímabilsins. Pví hverfur enginn sjóður úr gagnasettinu og par með er seiglubjögun ekki til staðar.

Pegar stuðlar jöfnu 1 voru metnir með skýrðu breytuna ávöxtun tiltekins sjóðs tiltekið ár og skýribreytuna ávöxtun sama sjóðs tveimur árum áđur kom í ljós að samkvæmnin sem hafði mælst í ávöxtun samliggjandi ára var horfin. Í stað hennar var komin örlítil ósamkvæmni eða endurhvarf til miðju. Metnir stuðlar voru neikvæðir og mjög nálægt núlli eða á bilinu -0,09 til -0,02, pótt peir virtust a.m.k. í sumum keyrslum tölfræðilega marktækt minni en núll. Рað samsvarar pví að einu prósentustigi meiri ávöxtun tiltekið ár skili sér í 0,02-0,09\% minni ávöxtun tveimur árum síðar.

Eignastýring lífeyrissjóða er í eðli sínu langtímaverkefni og pví skiptir e.t.v. ekki höfuðmáli hvort samkvæmni gætir yfir tveggja til priggja ára tímabil. Meiru skiptir hvort samkvæmni gæti yfir langan tíma. Í ljósi pess að byggt er á gögnum yfir 21 ár er hægt að kanna samkvæmni til nokkuð langs tíma hér. Í Gylfi Magnússon (2018) var kannað hvort samkvæmni gætti í ávöxtun fyrir hrun (1997-2008) annars vegar og eftir hrun (2009-2017) hins vegar. Í ljós kom að svo var ekki.

Tafla 3. Mat á jöfnu 1, öll ár

Núverandi sjóðir að teknu tilliti til ávöxtunar forvera.

Skýristærð ávöxtun tveimur árum áður.

\begin{tabular}{lcccccc}
\hline & $\beta$ & $t$ & $p$ & $r^{2}$ & $F$ & Frelsisgráður \\
\hline Hráar tölur & $-0,09$ & $-2,08$ & $1,91 \%$ & $0,9 \%$ & 4,316 & 467 \\
\hline Frávik frá meðaltali & $-0,02$ & $-0,48$ & $31,63 \%$ & $0,0 \%$ & 0,229 & 467 \\
\hline Frávik frá viðmiði & $-0,08$ & $-1,83$ & $3,38 \%$ & $0,7 \%$ & 3,356 & 467 \\
\hline
\end{tabular}

Hér var til viðbótar kannað hvort samkvæmni gætti yfir 5 ára tímabil, p.e. hvort ávöxtun tiltekins sjóðs tiltekið 5 ára tímabil gæfi vísbendingu um ávöxtun sama sjóðs næsta 5 ára tímabil. Í úrtakinu voru núverandi sjóðir að teknu tilliti til ávöxtunar forvera peirra. Tafla 4 sýnir niðurstöðurnar fyrir mat á stuðlum jöfnu 1. Eins og sjá má eru niðurstöðurnar nokkuð misvísandi, ekki tölfræðilega marktækar og formerki stuðla snýst við pegar skipt er frá pví að skoða frávik frá meðaltali yfir í frávik frá viðmiði. Рað er jafnframt í báðum tilfellum svo nálægt núlli að hagrænt mikilvægi er hverfandi. Pá er skýrimáttur jöfnunnar einnig hverfandi. Hana má pó e.t.v. túlka pannig að hún gefi engar skýrar vísbendingar um samkvæmni eða ósamkvæmni pegar horft er á 5 ára tímabil. 
Tafla 4. Mat á jöfnu 1, öll ár

Núverandi sjóðir að teknu tilliti til ávöxtunar forvera.

Skýrð stærð ávöxtun 5 ára tímabils, skýristærð ávöxtun næsta 5 ára tímabils á undan.

\begin{tabular}{lcccccc}
\hline & $\mathrm{b}$ & $\mathrm{t}$ & $\mathrm{p}$ & $\mathrm{r} 2$ & $\mathrm{~F}$ & Frelsisgráður \\
\hline Hráar tölur & $-0,20$ & $-8,62$ & $0,00 \%$ & $20,0 \%$ & 74,280 & 298 \\
\hline Frávik frá meðaltali & $-0,02$ & $-0,55$ & $29,04 \%$ & $0,1 \%$ & 0,306 & 298 \\
\hline Frávik frá viðmiði & 0,01 & 0,56 & $28,80 \%$ & $0,1 \%$ & 0,313 & 298 \\
\hline
\end{tabular}

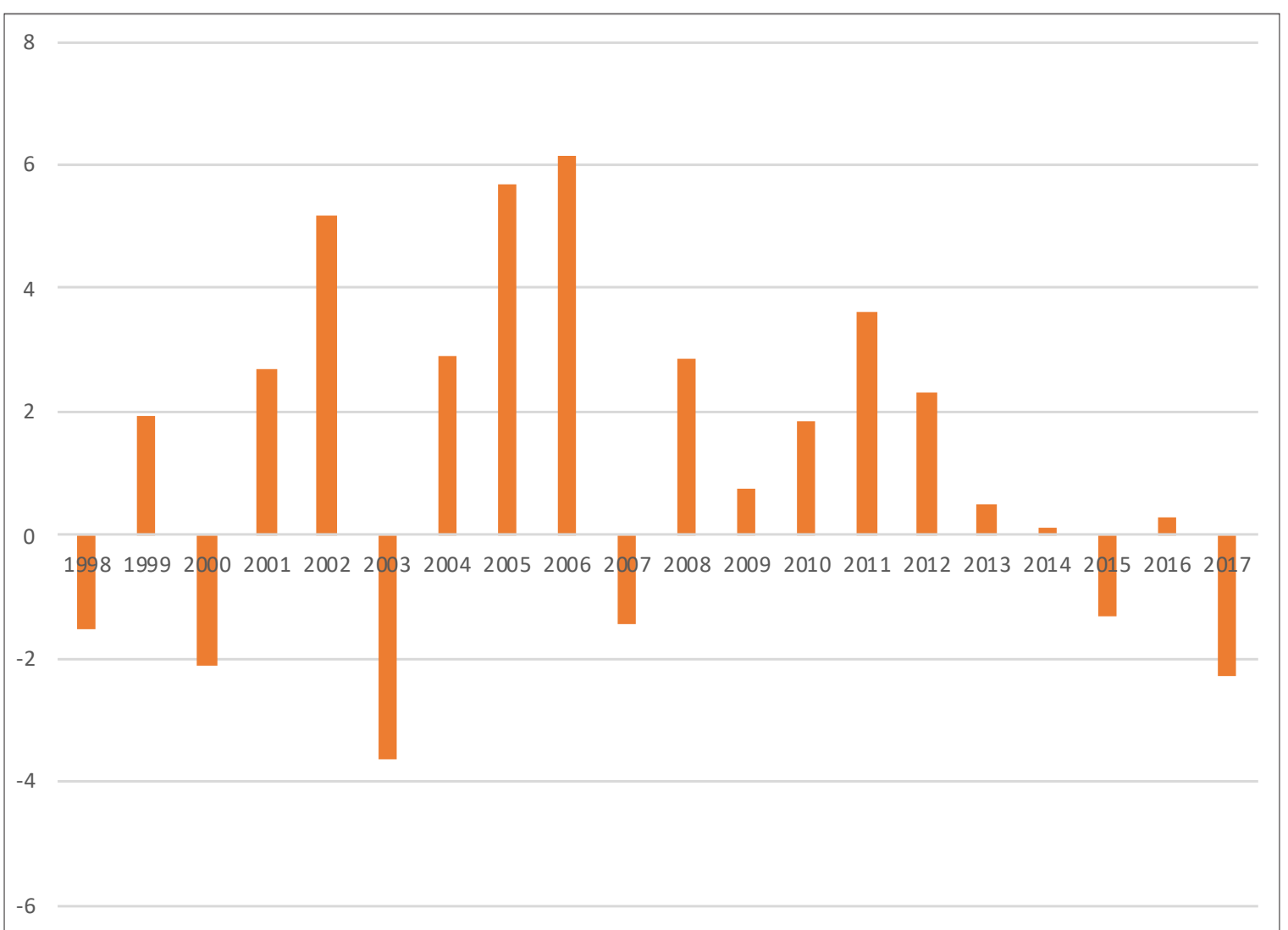

Mynd 4. Samkvæmni einstakra ára

t-stuðlar frá mati á jöfnu 1. Jákvætt samkvæmni, neikvætt ósamkvæmni.

Pegar sömu gögn voru notuð til að meta stuðla jafna 2 og 3 komu hins vegar fram pokkalega skýrar vísbendingar um ósamkvæmni, p.e. endurhvarf til miðjunnar. Við mat á jöfnu 2 fékkst $Q=7,41(p=0,65 \%)$ sem pýðir að hafna ætti $H_{0}$ tilgátunni um hvorki samkvæmni né ósamkvæmni. Pegar gögnin eru skoðuð sést að pað er vegna ósamkvæmni. Pannig ná 40,3\% peirra sjóða sem eru með ávöxtun yfir miðgildi (H) á tilteknu 5 ára tímabili einnig ávöxtun yfir miðgildi á næsta 5 ára tímabili en 59,7\% lenda pá undir miðgildi. Sömuleiðis ná 44,9\% peirra sjóða sem eru með ávöxtun undir miðgildi (L) á tilteknu 5 ára tímabili einnig ávöxtun undir miðgildi á næsta 5 ára tímabili en 55,1\% komast pá yfir miðgildi.

\section{Niðurstöður og umræða}

Nokkurrar samkvæmni virðist gæta í ávöxtun íslenskra lífeyrissjóða pegar horft er til skamms tíma. Hún virðist hins vegar hverfa og jafnvel að einhverju marki snúast við pegar horft er til lengri tíma. Petta kemur ekki á óvart og getur átt sér tiltölulega einfaldar hagrænar skýringar. Pannig myndi munur á áherslum í eignastýringu milli sjóða skila samkvæmni ef sveiflur í ávöxtun undirliggjandi eignaflokka (eða sveiflur í ávöxtun umfram viðmið) taka meira en eitt ár en jafnast út að einhverju marki pegar horft er til lengri tíma.

Niðurstöðurnar fyrir íslensku lífeyrissjóðina eru jafnframt í samræmi við erlendar 
rannsóknir á árangri í eignastýringu par sem samkvæmni virðist, ef eitthvað er, gæta til skamms tíma en ekki langs. Pá eru pær einnig í góðu samræmi við eldri íslenska rannsókn (Gylfi Magnússon o.fl. 2010) á samkvæmni í ávöxtun verðbréfasjóða.

Fyrir pá sem greiða í lífeyrissjóði (og geta valið sér sjóð) veita pessar niðurstöður ekki skýra vísbendingu um að pað borgi sig að velja sjóð út frá fortíðarávöxtun. Miðað við hve lítil samkvæmnin er og einungis til skamms tíma virðist pað pó ekki vera mjög líklegt til að skila miklu. Betra gæti verið að byggja valið á öðrum páttum en fortíðarávöxtun, eins og rakið er að nokkru marki í Gylfi Magnússon (2018), m.a. lýðfræðilegri samsetningu sjóðfélaga.

\section{Heimildir}

Adams, J. C., Nishikawa, T. og Rao, R. P. (2018). Mutual Fund Performance, Management Teams, and Boards. Journal of Banking and Finance. 92 (júlí), 358-368. https://doi.org/10.1016/j.jbankfin.2016.09.006

Angelidis, T., Giamouridis, D. og Tessaromatis, N. (2013). Revisiting Mutual Fund Performance Evaluation. Journal of Banking and Finance, 37, 1759-1776.

Chen, J., Hong, H., Huang, M. og Kubik, J. (2004). Does fund size erode mutual fund per-

formance? The role of liquidity and organization. American Economic Review, 94, 1276-1302.

Clare, A., Motson, N., Sapuric, S. og Todorovic, N. (2014). What Impact Does a Change of Fund Manager Have on Mutual Fund Performance? International Review of Financial Analysis. 35, 167-177. http://dx.doi. org/10.1016/j.irfa.2014.08.005

DeGroot, M. H. (1986). Probability and Statistics. Addison Wesley (2. útg.).

Fama, E. (1970). Efficient Capital Markets: A Review of Theory and Empirical Work. The Journal of Finance, 25(2), 383-417. doi:10.2307/2325486

Gylfi Magnússon, Haukur C. Benediktsson og Kári Sigurðsson. (2010). Er samkvæmni í árangri verðbréfasjóða? Tímarit um viðskipti og efnahagsmál, 7 (1), 97-114. https://doi.org/10.24122/tve.a.2010.7.1.6

Gylfi Magnússon. (2018). Ávöxtun og áhætta íslenskra lífeyrissjóða 1993-2017. Tímarit um viðskipti og efnahagsmál, 15 (2), 133-162. https://doi.org/10.24122/tve.a.2018.15.2.8

Grau-Carles, P., Doncel, L. M. og Sainz, J. (2017). Stability in Mutual Fund Performance Rankings: A New Proposal. International Review of Economics and Finance, 6 (C), 337-346. http://dx.doi.org/10.1016/j.iref.2018.01.018

Han, Y., Noe, T. H. og Rebello, M. J. (2008). Horses for Courses: Fund Managers and Organizational Structures. SSRN Working Papers. https://ssrn.com/abstract=1100676 eða http://dx.doi.org/10.2139/ssrn.1100676

Hunter, D., Kandel, E., Kandel, S. og Wermers, R. (2014). Mutual Fund Performance Evaluation with Active Peer Benchmarks. Journal of Financial Economics, 112 (1), 1-29. http://dx.doi.org/10.1016/j.jfineco.2013.12.006

Jenkinson, T., Jones H. og Martinez, J.V. (2016). Picking Winners? Investment Consultants ${ }^{`}$ Recommendations of Fund Managers. The Journal of Finance. LXXI (5), október, 2333-2369. DOI: 10.1111/jofi.12289

Jensen, M. (1968). The Performance of Mutual Funds in the Period 1945-1964. The Journal of Finance, 23 (2), 389416. doi:10.2307/2325404

Moneta. F. (2015). Measuring Mutual Fund Performance With Portfolio Characteristics. Journal of Empirical Finance, 33, 223-242. http://dx.doi.org/10.1016/j.jempfin.2015.03.012

Sharpe, W. F. (1966). Mutual Fund Performance. Journal of Business, 39 (S1), 119-138. doi:10.1086/294846.

Vidal-García, J. (2013). The Persistence of European Mutual Fund Performance. Research in International Business and Finance, 28, 45-67. http://dx.doi.org/10.1016/j.ribaf.2012.09.004

Vidal-García, J., Vidal, M., Boubaker, S. og Uddin, G. Z. (2016). The Short Term Persistence of International Mutual Fund Performance. Economic Modelling, 52, 926-938. http://dx.doi.org/10.1016/j.econmod.2015.10.031 


\section{Viðauki}

Tafla V1. Mat á jöfnu 2, öll ár

Án áhrifa samruna

Skýristærð ávöxtun ársins á undan

\begin{tabular}{|c|c|c|c|c|c|c|c|c|}
\hline Síðara ár & $\mathrm{HH}$ & $\mathrm{HL}$ & $\mathrm{LH}$ & LL & $\mathrm{E}$ & Q & Líkur & \\
\hline 2017 & 4 & 8 & 8 & 5 & 6,25 & 2,040 & $15,32 \%$ & Ósamkvæmni \\
\hline 2016 & 6 & 5 & 6 & 7 & 6 & 0,333 & $56,37 \%$ & Samkvæmni \\
\hline 2015 & 4 & 8 & 8 & 6 & 6,5 & 1,692 & $19,33 \%$ & Ósamkvæmni \\
\hline 2014 & 5 & 8 & 8 & 6 & 6,75 & 1,000 & $31,73 \%$ & Ósamkvæmni \\
\hline 2013 & 8 & 6 & 5 & 8 & 6,75 & 1,000 & $31,73 \%$ & Samkvæmni \\
\hline 2012 & 6 & 9 & 9 & 8 & 8 & 0,750 & $38,65 \%$ & Ósamkvæmni \\
\hline 2011 & 12 & 4 & 4 & 13 & 8,25 & 8,818 & $0,30 \%$ & Samkvæmni \\
\hline 2010 & 11 & 6 & 5 & 11 & 8,25 & 3,727 & $5,35 \%$ & Samkvæmni \\
\hline 2009 & 11 & 7 & 7 & 12 & 9,25 & 2,243 & $13,42 \%$ & Samkvæmni \\
\hline 2008 & 9 & 9 & 9 & 10 & 9,25 & 0,081 & $77,58 \%$ & Samkvæmni \\
\hline 2007 & 7 & 11 & 10 & 7 & 8,75 & 1,457 & $22,74 \%$ & Ósamkvæmni \\
\hline 2006 & 14 & 5 & 4 & 17 & 10 & 12,600 & $0,04 \%$ & Samkvæmni \\
\hline 2005 & 18 & 4 & 4 & 20 & 11,5 & 19,739 & $0,00 \%$ & Samkvæmni \\
\hline 2004 & 16 & 9 & 8 & 16 & 12,25 & 4,633 & $3,14 \%$ & Samkvæmni \\
\hline 2003 & 9 & 17 & 16 & 10 & 13 & 3,846 & $4,99 \%$ & Ósamkvæmni \\
\hline 2002 & 17 & 10 & 9 & 18 & 13,5 & 4,815 & $2,82 \%$ & Samkvæmni \\
\hline 2001 & 20 & 5 & 5 & 23 & 13,25 & 20,887 & $0,00 \%$ & Samkvæmni \\
\hline 2000 & 10 & 15 & 16 & 7 & 12 & 4,500 & $3,39 \%$ & Ósamkvæmni \\
\hline 1999 & 16 & 9 & 9 & 17 & 12,75 & 4,451 & $3,49 \%$ & Samkvæmni \\
\hline 1998 & 17 & 8 & 8 & 18 & 12,75 & 7,118 & $0,76 \%$ & Samkvæmni \\
\hline Öll árin & 220 & 163 & 158 & 239 & 195 & 25,405 & $0,00 \%$ & Samkvæmni \\
\hline
\end{tabular}


Tafla V2. Mat á jöfnu 3, öll ár

Án áhrifa samruna

Skýristærð ávöxtun ársins á undan

\begin{tabular}{lrrrl}
\hline Síðara ár & W & Röð af 5000 & Líkur & \\
\hline 2017 & -44 & 4277 & $14,5 \%$ & Ósamkvæmni \\
\hline 2016 & 1 & 2603 & $47,9 \%$ & Samkvæmni \\
\hline 2015 & -44 & 4259 & $14,8 \%$ & Ósamkvæmni \\
\hline 2014 & 32 & 1776 & $35,5 \%$ & Samkvæmni \\
\hline 2013 & 60 & 477 & $9,5 \%$ & Samkvæmni \\
\hline 2012 & -1 & 2588 & $48,2 \%$ & Ósamkvæmni \\
\hline 2010 & 154 & 23 & $0,5 \%$ & Samkvæmni \\
\hline 2009 & 102 & 255 & $5,1 \%$ & Samkvæmni \\
\hline 2008 & 68 & 908 & $18,2 \%$ & Samkvæmni \\
\hline 2007 & 62 & 967 & $19,3 \%$ & Samkvæmni \\
\hline 2006 & -102 & 3585 & $0,0 \%$ & Ósamkvæmni \\
\hline 2005 & 296 & 0 & $0,1 \%$ & Samkvæmni \\
\hline 2004 & 340 & 6 & $11,4 \%$ & Samkvæmni \\
\hline 2003 & 190 & 570 & $0,7 \%$ & Samkvæmni \\
\hline 2002 & -271 & 4965 & $0,1 \%$ & Ósamkvæmni \\
\hline 2001 & 349 & 3 & $0,0 \%$ & Samkvæmni \\
\hline 2000 & 547 & 1 & $2,5 \%$ & Samkvæmni \\
\hline 1999 & -201 & 10 & $0,2 \%$ & Ósamkvæmni \\
\hline 1998 & 335 & 0975 & Samkvæmni \\
\hline Öll árin & 230 & & Samkvæmni \\
\hline
\end{tabular}


